\title{
Humán inzulinról glargininzulin-alapú bázis-bolus kezelésre váltott betegek glykaemiás állapotának javulása a váltás után
}

\author{
Nagy Erzsébet dr. ${ }^{1}$ - Kovács Gábor dr. ${ }^{2}$ \\ ${ }^{1}$ Zuglói Egészségügyi Szolgálat, Budapest \\ ${ }^{2}$ Medico-Eco Egészségügyi Szolgáltató, Budapest
}

\begin{abstract}
Bevezetés: A humán inzulinok és az inzulinanalógok hatékonysága hasonló, de az utóbbiaknak kedvezőbb a farmakokinetikájuk, amivel kevesebb hypoglykaemia és az élettanihoz hasonlóbb inzulinprofil érhető el.

Célkitüzés: Annak igazolása, hogy a humán bázis-bolus inzulinkezelésről glargininzulin-alapú bázis-bolus kezelésre váltva jobb glykaemiás kontroll biztosítható.

Módszer: A 12 hónapos retrospektív adatgyúijtéssel kiegészített 3 hónapos prospektív, beavatkozással nem járó vizsgálatba olyan betegek kerültek, akiket a beválasztáskor váltottak glargininzulin- - $100 \mathrm{E} / \mathrm{ml}$ - alapú bázis-bolus inzulinkezelésre, nem volt megfeleló a vércukorháztartásuk, és a bevonást megelóző 12 hónapból legalább további egy $\mathrm{HbA}_{1 c}$-eredménnyel rendelkeztek. Az 1513 bevont beteg közül 1181 betegnek álltak rendelkezésre a hatásossági elemzéshez szükséges adatai.

Eredmények: A bevonáskor átlagosan 58,3 éves betegek 48,1\%-a volt férfi. Az analóg inzulinra váltást megelőző évben a betegek átlagos $\mathrm{HbA}_{1 c}$-szintje lényegében stagnált: a váltás előtt 12 hónappal $8,8 \pm 1,4 \%$, a váltáskor $8,8 \pm 1,2 \%$ volt, a váltás után 3 hónappal viszont szignifikánsan csökkent $7,7 \pm 1,0 \%$ értékre $(\mathrm{p}<0,001)$. A váltás és a 3 . hónap között szignifikánsan csökkent az éhomi vércukorszint $(10,0 \pm 3,2 \mathrm{mmol} / \mathrm{l}$-ről 7,4 $\pm 1,9 \mathrm{mmol} / \mathrm{l}-\mathrm{re}, \mathrm{p}<0,001)$ és a postprandialis vércukorszint is $(11,1 \pm 2,8 \mathrm{mmol} / \mathrm{l}$-ról $8,8 \pm 1,7 \mathrm{mmol} / \mathrm{l}-\mathrm{re}, \mathrm{p}<0,001)$. Az inzulinok dózisát a váltást megelőzően és azt követően is növelték.

Következtetések: A glargininzulin-alapú bázis-bolus kezelés szignifikáns javulást tudott elérni olyan betegek glykaemiás állapotában, akik nem voltak megfelelően beállítva a váltást megelőzően.
\end{abstract}

Orv Hetil. 2018; 159(29): 1201-1207.

Kulcsszavak: 2-es típusú cukorbetegség, hosszú hatású inzulinok, glargin inzulin

\section{Improvement in the glycaemic control of patients after switching from human insulin to insulin glargine-based basal-bolus regimen}

Introduction: The effectiveness of human and analogue insulins is similar but the latter have more advantageous pharmacokinetic features, leading to an improvement in hypoglycaemia and come closer to achieving the physiologic insulin profile.

Aim: To demonstrate that switching from a human basal-bolus insulin treatment to an insulin glargine-based basalbolus regimen can achieve a better glycaemic control.

Method: This 3-month prospective, non-interventional study, including a 12 -month retrospective data collection phase, enrolled patients who were switched to the insulin glargine- - $100 \mathrm{U} / \mathrm{mL}$ - based basal-bolus treatment at the time of enrolment if they were inadequately controlled and had at least one additional $\mathrm{HbA}_{1 \mathrm{c}}$ result in the 12 months before the switch. Of 1513 patients 1181 had the data that were needed for the efficacy analysis.

Results: The mean age of the efficacy population was 58.3 years and $48.1 \%$ were male. Their mean $\mathrm{HbA}_{\mathrm{lc}}$ levels remained unchanged in the year before the switch: it was $8.8 \pm 1.4 \%$ at 12 months prior to the switch and $8.8 \pm 1.2 \%$ at the switch, but decreased significantly to $7.7 \pm 1.0 \%(\mathrm{p}<0.001)$ after 3 months. Between the baseline and 3 months, the fasting blood glucose and the postprandial blood glucose improved significantly (from $10.0 \pm 3.2$ $\mathrm{mmol} / \mathrm{L}$ to $7.4 \pm 1.9 \mathrm{mmol} / \mathrm{L}, \mathrm{p}<0.001$ and from $11.1 \pm 2.8 \mathrm{mmol} / \mathrm{L}$ to $8.8 \pm 1.7 \mathrm{mmol} / \mathrm{L}, \mathrm{p}<0.001$, respectively). Insulin doses were increased both before and after the switch. 
Conclusions: Switch to an insulin glargine-based basal-bolus regimen could achieve a significant improvement in the glycaemic control in patients who were inadequately controlled prior to the switch.

Keywords: diabetes mellitus type 2, long acting insulin, insulin glargine

Nagy E, Kovács G. [Improvement in the glycaemic control of patients after switching from human insulin to insulin glargine-based basal-bolus regimen]. Orv Hetil. 2018; 159(29): 1201-1207.

(Beérkezett: 2017. november 27.; elfogadva: 2018. március 27.)

\section{Rövidítések}

$\mathrm{BMI}=($ body mass index $)$ testtömegindex $; \mathrm{E}=$ egység; $\mathrm{HbA}_{\mathrm{lc}}$ $=$ hemoglobin-A-lc; IGFl $=$ (insulin-like growth factor $)$ inzulinszerü növekedési faktor- $1 ; \mathrm{NE}=$ nemzetközi egység; $\mathrm{NPH}=$ neutrális protamin Hagedorn (inzulin); $\mathrm{OAD}=$ orális antidiabetikum; $\mathrm{SD}=($ standard deviation $)$ standard szórás

A Magyar Diabetes Társaság - a nemzetközi társaságok ajánlásaival összhangban - célértékeket, terápiás javaslatokat fogalmazott meg a 2-es típusú cukorbetegek kezelésével kapcsolatban $[1,2]$. A célértékek meghatározása azért nagyon fontos, mert az emelkedett éhomi vércukorértékek a mortalitás nagyobb rizikójához vezethetnek, valamint a postprandialis vércukorértékek szoros összefüggést mutatnak a szövődmények kialakulásával és progressziójával [3]. A 2-es típusú cukorbetegségben szenvedők kezelése esetén a betegség progresszív jellegéből adódóan gyakran inzulinkezeléssel lehet megfelelő anyagcsere-állapotot biztosítani. A terápia megtervezésekor nagyon fontos, hogy az egyénre szabott legyen, $\mathrm{s}$ a lehetô legjobb anyagcsere-állapotot biztosítsa $[4,5]$. Figyelembe kell még venni a beteg életkorát, testsúlyát, a diabetes fennállásának idejét, a betegség stádiumát, a kísérő betegségeket, a diabetesszel összefüggő esetleges szövődményeket, a hypoglykaemiás előzményeket és hajlamot is. A monokomponensû́ inzulinoktól az inzulinanalógok megjelenéséig eltelt évek, évtizedek során különböző inzulinkezelési formák alakultak ki, de még mindig nem egyértelmú, hogy melyik az ideális kezelési forma. Az inzulinkezelés alapját napjainkban a humán inzulinok alkotják, és különböző hatáskezdetű, hatástartamú, eltérő felszívódású inzulinok kombinációjával törekszünk az ideális állapot elérésére [6]. Érdemes felhívni a figyelmet arra, hogy a 2-es típusú diabetes kezelése során indokolt a korábbi metforminkezelés megtartása - amennyiben ellenjavallat nem áll fenn -, bármelyik terápiás rezsimet választjuk is (legyen az kombinált orális vagy kombinált inzulinkezelés) [1]. A napi gyakorlatban a humáninzulin-kezelés során nehézséget jelenthet az étkezéseknek és az inzulinadagolásnak az összehangolása a beteg életformájával, valamint a hypoglykaemia kialakulásának és a testsúlynövekedésnek a kockázata. Az inzulinanalógok kifejlesztésének egyik célja éppen a humáninzulin-kezelésből adódó problémák megszüntetése, a flexibilisebb életformával javuló anyagcsere-állapot eléré- se volt. A humán inzulinok és az inzulinanalógok hatékonysága hasonló, de az utóbbiak kedvezőbb farmakokinetikai tulajdonságokkal rendelkeznek, s így alkalmazásukkal a fiziológiás inzulinprofil jobban elérhető. Ennek eredménye hosszú távon a diabetesszövődmények gyakoriságának és/vagy súlyosságának a csökkenése lehet, amit több vizsgálat eredménye is alátámasztott mind l-es típusú, mind kevert ( 1 -es és 2 -es típusú) cukorbeteg-populációban [7-9].

Az ismételt éjszakai hypoglykaemia a bázisinzulin-analóg adásának abszolút indikációját jelenti. A humán bázisinzulinnal nem befolyásolható, jelentős mértékü „dawn-phenomenon” ( „hajnali jelenség”) is a bázisinzulin-analógra történő változtatást indokolja [10].

A glargin inzulin a humán inzulin kémiai szerkezetének módosításával létrehozott hosszú hatású inzulinanalóg. Az A-lánc a 2l-es pozíciójában aszparagin helyett glicint tartalmaz, míg a B-lánc C-terminális végén kialakított oldalláncban további két arginin kapott helyet [11].

A glargin inzulinnak az inzulinreceptorhoz való kötődési kinetikája a humán inzulinéval megegyező, az IGFlreceptorhoz viszont - in vitro vizsgálatok szerint - nagyobb affinitással kötődik. Hatásgörbéje nagyon hasonló az élettani bazálisinzulin-elválasztáshoz, ezért lehet ideális bázisinzulin [12].

A glargin inzulin relatív csúcshatásmentes az NPH-inzulinokkal összehasonlítva, ami lehetővé teszi a napi egyszeri adagolást, $\mathrm{s}$ ezáltal kiválthatja a naponta többször alkalmazott NPH-kat $[13,14]$. A glükózanyagcserére kifejtett teljes napi aktivitása nem függ attól, hogy a nap folyamán mikor alkalmazzák, és a Lantus jelenlegi alkalmazási előírása is csak azt javasolja, hogy a beadás időpontja minden nap azonos legyen [14-16]. A naponta egyszer adott glargin inzulin legalább olyan hatásos a glykaemiás állapot fenntartásában, mint a naponta egyszer vagy kétszer alkalmazott NPH-inzulin [17-19], viszont kisebb a hypoglykaemaincidencia [20]. Az ATLANTUS vizsgálat eredményei arra utaltak, hogy a glargin inzulint lefekvéskor alkalmazva úgy javul a korábbi anyagcserehelyzet, hogy a súlyos hypoglykaemiák száma alacsony, és a testsúlynövekedés sem jelentős (az esetek nagy részében megtartott orális antidiabetikus kezelés mellett) [21]. További elónyt jelent még, hogy glargin inzulin mellett a postprandialis vércukorértékek 
is jobb anyagcserekontrollra utaltak, mint az NPH-inzulin mellett [22].

A humán bázis-bolus kezelésről analóg bázis-bolus kezelésre történő váltás a magyar finanszírozási rendszer következménye, az erre vonatkozó adat igen csekély az irodalomban [23]. A jelen vizsgálattal azt kívántuk igazolni, hogy a humáninzulin-kezelésről glargin inzulin $100 \mathrm{E} / \mathrm{ml}$ és gyors hatású inzulin kombinációjára való váltás jobb glykaemiás kontrollt biztosít, mint a megelöző humáninzulin-kezelés.

\section{Módszer}

A vizsgálati cél elérése érdekében prospektív, beavatkozással nem járó vizsgálatot végeztünk olyan betegek bevonásával, akik 2-es típusú diabetes mellitusban szenvedtek, betöltötték a 18. életévüket, a glargin inzulin 100/ $\mathrm{ml}$ (Lantus) és gyors hatású inzulin kombinációjára váltáskor mért $\mathrm{HbA}_{1 \mathrm{c}}$-értékük legalább 7\% volt, és a terápiaváltást megelőző 12 hónapban legalább még egy $\mathrm{HbA}_{\mathrm{lc}}$-mérési eredménnyel rendelkeztek. A glykaemiás és a terápiás adatok rögzítésére a terápiaváltás időpontjával megegyező bevonáskor (1. vizit), valamint 3 hónappal később (2. vizit) került sor, emellett a bevonáskor rögzítésre kerültek a beválasztást megelőző 12 hónapból rendelkezésre álló $\mathrm{HbA}_{1 \mathrm{c}}$-értékek és inzulindózisok is. A vizsgálat obszervációs jellegéből adódóan kötelező kivizsgálás és kezelés nem volt előírva, ezekről a vizsgáló az érvényes szakmai ajánlások, valamint a gyógyszerek alkalmazási előírása szerint döntött.

Az elemzés biztonságossági és hatásossági elemzésből tevődött össze. A biztonságossági elemzés a nemkívánatos és a hypoglykaemiás eseményekre vonatkozott, és azon betegek adatai alapján készült, akiknek az 1 . viziten mért adatai rendelkezésre álltak $(\mathrm{n}=1513)$. A hatásossági elemzés a glykaemiás értékek, a testtömegindex és a gyógyszeres kezelés változását tárta fel, és a biztonságossági populáció azon betegeinek adatai alapján készült, akiknek rendelkezésre állt a $\mathrm{HbA}_{1 \mathrm{c}}$-szintjük a bevonáskor, a bevonás után 3 hónappal és a megelőző 12 hónapban legalább egy alkalommal $(\mathrm{n}=1181)$. A glargin inzulinra történt váltást követően a betegek kaphattak humán és analóg gyors hatású inzulint. Két alcsoportot képeztünk aszerint, hogy a betegek mindkét viziten humán inzulint $(\mathrm{n}=53)$ vagy mindkét viziten inzulinanalógot kaptak $(\mathrm{n}=1081)$ : kizártuk ebból az alcsoportelemzésből azokat, akiknek a két viziten eltérő típusú gyors hatású inzulint írtak fel $(\mathrm{n}=15)$, vagy a gyors hatású inzulin típusa nem volt ismert mindkét viziten $(n=32)$.

A folytonos változók bemutatására esetszámot, átlagot és standard szórást, a kategoriális változókéra esetszámot és gyakoriságot használtunk. A változók időbeli és csoportok közötti összehasonlítására haszált statisztikai próbákat az egyes elemzéseknél a táblázatokban adtuk meg. A változók normális eloszlását $\mathrm{Q}-\mathrm{Q}$ plotok segítségével vizsgáltuk. A statisztikai szignifikanciát $\mathrm{p}<0,05$ értéknél mondtuk ki. A glargin inzulin mellé a humán vagy ana- lóg gyors hatású inzulint használó betegek számának igen nagy, közel húszszoros különbsége miatt e két csoport összehasonlításában csak leíró statisztikai eredményeket adtunk meg, statisztikai összehasonlítást nem végeztünk.

A vizsgálatot („Solar”) az Egészségügyi Tudományos Tanács Tudományos és Kutatásetikai Bizottsága engedélyezte (az engedélyező határozat száma: 12361-0/2011EKU).

\section{Eredmények}

\section{Kiindulási és kórelózményi adatok}

A hatásossági populáció $48,1 \%$-a volt férfi. A bevonáskor átlagosan 58,3 éves betegek cukorbetegségét átlagosan mintegy 10 évvel korábban ismerték fel; ók a diagnosztizálás után 3,6 évvel kezdtek el valamilyen OAD-t szedni, illetve 5,9 évvel utána bázisinzulint, 6,1 évvel utána pedig humán gyors hatású inzulint alkalmazni (1. táblázat). A bevonáskor a betegek mintegy felének $(50,8 \%)$ volt már micro- vagy macrovascularis szövődménye.

1. táblázat |A diabeteses betegek kórelőzménye

\begin{tabular}{lcc}
\hline Mért változók & $\mathrm{n}$ & Átlag $\pm \mathrm{SD}$ \\
\hline Életkor (év) & & \\
\hline A vizsgálatba való beválasztás idején & 1181 & $58,3 \pm 11,4$ \\
A diabetes mellitus diagnózis felállítása & 1164 & $48,4 \pm 11,3$ \\
idején & & \\
\hline A diabetes mellitus fennállásának & & \\
időtartama (év) & 1164 & $10,0 \pm 7,2$ \\
\hline A bevonás időpontjában & 836 & $3,6 \pm 5,1$ \\
Az OAD-kezelés kezdetekor & 981 & $5,9 \pm 5,7$ \\
A bázisinzulin-kezelés kezdetekor & 994 & $6,1 \pm 5,8$ \\
A humán gyors hatású inzulinkezelés & & \\
kezdetekor & & \\
& &
\end{tabular}

$\mathrm{OAD}=$ orális antidiabetikum; SD = standard szórás

\section{A vércukorháztartás értékei}

A $H b A_{l c}$-szint változása. A bevonást megelőző 12 hónapban a $\mathrm{HbA}_{\mathrm{lc}}$-érték lényegében változatlan maradt: a megelőző 12 . hónaptól a megelőző 3 . hónapig $8,8 \pm$ $1,4 \%$-ról $8,7 \pm 1,3 \%$-ra módosult $(\mathrm{p}=0,018)$, majd a bevonáskor ismét $8,8 \pm 1,2 \%$ lett (2. táblázat). A bevonás utáni 3 . hónapra viszont szignifikáns mértékben, $7,7 \pm 1,0 \%$-ra csökkent (3. táblázat). Az átlagos $\mathrm{HbA}_{\mathrm{lc}^{-}}$ szint szignifikánsan csökkent a glargin inzulin mellé gyors hatású humán inzulint alkalmazók $(8,7 \pm 1,1 \%$-ról $8,0 \pm 1,2 \%$-ra, $\mathrm{p}<0,001)$ és a gyors hatású inzulinanalógot alkalmazók körében is $(8,8 \pm 1,2 \%$-ról 7,6 \pm 1,0\%-ra, $\mathrm{p}<0,001)$. A gyors hatású inzulinanalógot alkalmazó betegek alcsoportjában átlagosan nagyobb mértékű $\mathrm{HbA}_{\mathrm{lc}^{-}}$ csökkenés volt megfigyelhető. A bevonáskor mért 
$\mathrm{HbA}_{\mathrm{lc}}$-szint sem a diabetes mellitus fennállásának időtartamával, sem a megelőző humáninzulin-kezelés hoszszával nem mutatott statisztikailag szignifikáns összefüggést.

\section{Éhomi vércukorszint}

A betegek éhomi vércukorszintje a bevonás, majd az azt követő 3. hónap között szignifikánsan csökkent: 10,0 \pm $3,2 \mathrm{mmol} / 1$-rôl (2. táblázat) $7,4 \pm 1,9 \mathrm{mmol} / \mathrm{l}$-re $(\mathrm{p}<0,001)$ (3. táblázat). Az éhomi vércukorszint szignifikánsan csökkent a glargin inzulin mellett gyors hatású humán inzulint $(10,8 \pm 3,4 \mathrm{mmol} / \mathrm{l}$-ról $7,9 \pm 2,9$ mmol/1-re, $\mathrm{p}<0,001)$ és a gyors hatású inzulinanalógot alkalmazók körében is $(9,9 \pm 3,2 \mathrm{mmol} / 1$-ről 7,4 $\pm 1,8$ mmol/1-re, $\mathrm{p}<0,001)$. A gyors hatású humán inzulint alkalmazó betegek alcsoportjában átlagosan nagyobb mértékü éhomi vércukorszint-csökkenés volt megfigyelhető.

\section{Postprandialis vércukorszint}

A betegek postprandialis vércukorszintje a bevonás, majd az azt követő 3. hónap között szignifikánsan csökkent: $11,1 \pm 2,8 \mathrm{mmol} / 1$-ról (2. táblázat) $8,8 \pm 1,7 \mathrm{mmol} / \mathrm{l}$ re $(\mathrm{p}<0,001)$ (3. táblázat). Az átlagos postprandialis vércukorszint szignifikánsan csökkent a glargin inzulin mellett gyors hatású humán inzulint $(11,6 \pm 2,8 \mathrm{mmol} / 1$-ről $9,5 \pm 2,1 \mathrm{mmol} / \mathrm{l}-\mathrm{re}, \mathrm{p}<0,00 \mathrm{l})$ és a gyors hatású inzulinanalógot alkalmazók körében is $(11,1 \pm 2,8 \mathrm{mmol} / \mathrm{l}$ ról 8,7 $\pm 1,6 \mathrm{mmol} / 1-\mathrm{re}, \mathrm{p}<0,001)$. A gyors hatású analóg inzulint alkalmazó betegek alcsoportjában átlagosan nagyobb mértékü postprandialis vércukorszint-csökkenés volt megfigyelhető.

\section{Testtömegindex (BMI)}

A betegek BMI-je szignifikánsan, $31,1 \pm 5,3 \mathrm{~kg} / \mathrm{m}^{2}$-ról (2. táblázat) $30,8 \pm 5,2 \mathrm{~kg} / \mathrm{m}^{2}$-re (3. táblázat) csökkent a bevonás és a 3 . hónap között $(\mathrm{p}<0,001)$.

2. táblázat $\mid$ A bevont betegeknek a bevonáskor, valamint a $\mathrm{HbA}_{1 \mathrm{c}}$-nek, a humán bázis- és a humán gyors hatású inzulinnak a bevonás előtti 12 hónapban mért értékei és a bevonás elötti változások statisztikai értékelése

\begin{tabular}{|c|c|c|c|}
\hline $\begin{array}{l}\text { Mért változók a bevonáskor és az azt megelőző } 12 \\
\text { hónapban }\end{array}$ & $\mathrm{n}$ & Átlag \pm SD & $\begin{array}{l}\text { Összehasonlítás } \\
\text { (Wilcoxon-teszt) }\end{array}$ \\
\hline \multicolumn{4}{|l|}{$H b A_{l c}(\%)$} \\
\hline A bevonás előtt 12 hónappal & 691 & $8,8 \pm 1,4$ & \\
\hline A bevonás előtt 9 hónappal & 592 & $8,6 \pm 1,3$ & \\
\hline A bevonás előtt 6 hónappal & 693 & $8,6 \pm 1,2$ & \\
\hline A bevonás előtt 3 hónappal & 915 & $8,7 \pm 1,3$ & $\begin{array}{l}\text { A bevonás előtt } 12 \text { hónappal mért értékkel összeha- } \\
\text { sonlítva: } \mathrm{p}=0,018\end{array}$ \\
\hline A bevonáskor & 1181 & $8,8 \pm 1,2$ & \\
\hline Éhomi vércukorszint (mmol/l) a bevonáskor & 1178 & $10,0 \pm 3,2$ & \\
\hline Postprandialis vércukorszint (mmol/l) a bevonáskor & 1079 & $11,1 \pm 2,8$ & \\
\hline$B M I\left(\mathrm{~kg} / \mathrm{m}^{2}\right)$ a bevonáskor & 1140 & $31,1 \pm 5,3$ & \\
\hline \multicolumn{4}{|l|}{ Humán bázisinzulinok napi dózisa (NE) } \\
\hline A bevonás előtt 12 hónappal & 655 & $23,2 \pm 14,0$ & \\
\hline A bevonás előtt 9 hónappal & 611 & $24,7 \pm 14,0$ & \\
\hline A bevonás előtt 6 hónappal & 709 & $26,1 \pm 13,9$ & \\
\hline A bevonás előtt 3 hónappal & 902 & $27,7 \pm 15,2$ & $\begin{array}{l}\text { A bevonás előtt } 12 \text { hónappal alkalmazott dózissal } \\
\text { összehasonlítva: } \mathrm{p}<0,001\end{array}$ \\
\hline \multicolumn{4}{|l|}{ Humán gyors hatású inzulinok napi dózisa (NE) } \\
\hline A bevonás előtt 12 hónappal & 641 & $33,9 \pm 16,1$ & \\
\hline A bevonás előtt 9 hónappal & 602 & $34,9 \pm 16,2$ & \\
\hline A bevonás előtt 6 hónappal & 710 & $37,2 \pm 19,1$ & \\
\hline A bevonás előtt 3 hónappal & 919 & $38,2 \pm 16,7$ & $\begin{array}{l}\text { A bevonás előtt } 12 \text { hónappal alkalmazott dózissal } \\
\text { összehasonlítva: } \mathrm{p}<0,001\end{array}$ \\
\hline A glargin inzulin dózisa (E) a bevonáskor & 1181 & $29,0 \pm 16,8$ & \\
\hline $\begin{array}{l}\text { Analóg gyors hatású inzulinok napi dózisa (E) a } \\
\text { bevonáskor }\end{array}$ & 1081 & $35,4 \pm 16,6$ & \\
\hline $\begin{array}{l}\text { Humán gyors hatású inzulinok napi dózisa }(E) \text { a } \\
\text { bevonáskor }\end{array}$ & 53 & $35,9 \pm 14,8$ & \\
\hline
\end{tabular}

$\mathrm{BMI}=$ testtömegindex $\mathrm{HbA}_{\mathrm{lc}}=$ hemoglobin-A-1c; $\mathrm{SD}=$ standard szórás 


\section{Antidiabetikus kezelés}

Bázisinzulin-kezelés. A vizsgálatot megelőző 12 hónapban a humán bázisinzulin napi dózisát 23,2 \pm 14,0 NE-ról egyenletesen $27,7 \pm 15,2$ NE-re emelték (a bevonás előtti 12. és 3. hónapot összehasonlítva a növekedés statisztikailag szignifikánsnak bizonyult, $\mathrm{p}<0,001$ ) (2. táblázat). A glargin inzulinra történt váltáskor rendelt $29,0 \pm 16,8 \mathrm{E}$ dózist a 3. hónapig szignifikáns mértékben, 31,9 $\pm 16,6$ E-re növelték $(\mathrm{p}<0,001)$ (3. táblázat). A betegek 79,2\%-a alkalmazta este 20:00 és 22:00 között a glargin inzulint.

\section{A glargin inzulin dózisa a betegek alcsoportjaiban}

A bevonáskor szignifikánsan nagyobb dózisban rendelték a glargin inzulint azoknak, akiknek a bevonáskor mért $\mathrm{HbA}_{\mathrm{lc}}$-szintje meghaladta a 10\%-ot, szemben azokkal, akiknek nem haladta meg $(33,3 \pm 19,4 \mathrm{E} /$ nap versus $29,2 \pm 16,7 \mathrm{E} / \mathrm{nap}, \mathrm{p}<0,015)$. Ugyancsak szignifikáns különbség mutatkozott a bevonáskor elrendelt glargin inzulin dózisában a $30 \mathrm{~kg} / \mathrm{m}^{2}$ értéket meghaladó és az azt nem meghaladó testtömegindexű betegek között $(33,0 \pm 20,0 \mathrm{E} /$ nap versus $25,5 \pm 11,6 \mathrm{E} / \mathrm{nap}$, $\mathrm{p}<0,001$ ) (4. táblázat).

\section{Gyors hatású inzulinkezelés}

A vizsgálatot megelőző 12 hónapban a gyors hatású humán inzulin napi dózisát is folyamatosan emelték $(33,9 \pm$ 16,1 NE-ról 38,2 + 16,7 NE-re, p<0,001) (2. táblázat). A glargin inzulinra történt váltást követő 3 hónapban mind a humáninzulin-kezelésben, mind a gyors hatású analóginzulin-kezelésben részesülők napi dózisát szignifikánsan emelték (az előbbiekét 35,9 \pm 14,8 E/napról $37,4 \pm 15,8 \mathrm{E} /$ napra, az utóbbiakét 35,4 \pm 16,6 E/napról $37,2 \pm 18,1 \mathrm{E} /$ napra, mindkét alcsoportban $\mathrm{p}<0,001$ ) (3. táblázat).

\section{A bázisinzulin aránya}

A bázisinzulin aránya a napi inzulindózison belül a terápiaváltás előtti 12 hónapban alig változott: 40,1\%-ról 41,2\%-ra növekedett. Azoknak a betegeknek, akiknek a glargin inzulinra váltáskor gyors hatású inzulinanalógot rendeltek, a bázisinzulin aránya a bevonáskor $45 \%$, az azt követő 3 . hónapban $46,5 \%$ volt. Akiknek viszont a glargin inzulin mellé humán gyors hatású inzulint írtak fel, a bázisinzulin aránya a bevonáskor csak $38,2 \%$ volt, és a 3 . hónapban is csak 40,1\% lett.

\section{Biztonságossági eredmények}

A vizsgálat ideje alatt nemkívánatos eseményt nem jelentettek.

A biztonságossági elemzésben figyelembe vett 1513 beteg közül 197 betegben regisztráltak összesen 671
3. táblázat

A $\mathrm{HbA}_{1 \mathrm{c}}$-nek, az éhomi vércukornak, a postprandialis vércukornak és a BMI-nek a bevonást követő 3 . hónapban mért értékei, az alkalmazott glargin, humán és analóg gyors hatású inzulindózisok, valamint ezek változásainak statisztikai értékelése

\begin{tabular}{|c|c|c|c|}
\hline $\begin{array}{l}\text { Mért változók a bevonást } \\
\text { követő } 3 \text {. hónapban }\end{array}$ & $\mathrm{n}$ & Átlag \pm SD & $\begin{array}{l}\text { Változás a } \\
\text { bevonáskor } \\
\text { mért értékkel } \\
\text { összehasonlítva } \\
\text { (Wilcoxon- } \\
\text { teszt) }\end{array}$ \\
\hline $\mathrm{HbA}_{\mathrm{lc}}(\%)$ & 1181 & $7,7 \pm 1,0$ & $\mathrm{p}<0,001$ \\
\hline $\begin{array}{l}\text { Éhomi vércukorszint } \\
(\mathrm{mmol} / \mathrm{l})\end{array}$ & 1178 & $7,4 \pm 1,9$ & $\mathrm{p}<0,001$ \\
\hline $\begin{array}{l}\text { Postprandialis vércukorszint } \\
(\mathrm{mmol} / \mathrm{l})\end{array}$ & 1052 & $8,8 \pm 1,7$ & $\mathrm{p}<0,001$ \\
\hline $\operatorname{BMI}\left(\mathrm{kg} / \mathrm{m}^{2}\right)$ & 1099 & $30,8 \pm 5,2$ & $\mathrm{p}<0,001$ \\
\hline A glargin inzulin dózisa (E) & 1177 & $31,9 \pm 16,6$ & $\mathrm{p}<0,001$ \\
\hline $\begin{array}{l}\text { Gyors hatású inzulin- } \\
\text { analógok napi dózisa (E) }\end{array}$ & 1081 & $37,2 \pm 18,1$ & $\mathrm{p}<0,001$ \\
\hline $\begin{array}{l}\text { Gyors hatású humán } \\
\text { inzulinok napi dózisa }(\mathrm{E})\end{array}$ & 53 & $37,4 \pm 15,8$ & $\mathrm{p}<0,001$ \\
\hline
\end{tabular}

$\mathrm{BMI}=$ testtömegindex $; \mathrm{HbA}_{\mathrm{lc}}=$ hemoglobin- $\mathrm{A}-\mathrm{lc} ; \mathrm{SD}=$ standard szórás

4. táblázat $\mid$ A bevonáskor alkalmazott glargin inzulin dózisa a bevonáskor mért $\mathrm{HbA}_{\mathrm{lc}}$ és $\mathrm{BMI}$ alapján képezett alcsoportokban

\begin{tabular}{|c|c|c|c|}
\hline Alcsoportok & $\mathrm{n}$ & Átlag \pm SD & $\begin{array}{l}\text { Az alcsoportok } \\
\text { közötti } \\
\text { összehasonlítás } \\
\text { (Mann-Whitney- } \\
\text { féle U-teszt) }\end{array}$ \\
\hline \multicolumn{4}{|c|}{$\begin{array}{l}\text { A glargin inzulin dózisa } \\
\text { (E) a bevonáskor mért } \\
H b A_{1 c} \text { szerint képezett } \\
\text { alcsoportokban }\end{array}$} \\
\hline $\mathrm{HbA}_{\mathrm{lc}} \leq 10 \%$ & 947 & $29,2 \pm 16,7$ & $\mathrm{p}<0,015$ \\
\hline $\mathrm{HbA}_{\mathrm{lc}}>10 \%$ & 134 & $33,3 \pm 19,4$ & \\
\hline \multicolumn{4}{|c|}{$\begin{array}{l}\text { A glargin inzulin dózisa } \\
\text { (E) a bevonáskor mért BMI } \\
\text { értéke szerint képezett } \\
\text { alcsoportokban }\end{array}$} \\
\hline $\mathrm{BMI} \leq 30 \mathrm{~kg} / \mathrm{m}^{2}$ & 463 & $25,5 \pm 11,6$ & $\mathrm{p}<0,001$ \\
\hline $\mathrm{BMI}>30 \mathrm{~kg} / \mathrm{m}^{2}$ & 577 & $33,0 \pm 20,0$ & \\
\hline
\end{tabular}

$\mathrm{BMI}=$ testtömegindex $; \mathrm{Hb}_{\mathrm{lc}}=$ hemoglobin- $\mathrm{A}-\mathrm{lc} ; \mathrm{SD}=$ standard szórás

\begin{tabular}{l|l} 
5. táblázat & $\begin{array}{l}\text { A nem súlyos és a súlyos hypoglykaemiás események incidencia- } \\
\text { súrúsége a gyors hatású humán és a gyors hatású analóg inzulint } \\
\text { használók körében }\end{array}$
\end{tabular}

\begin{tabular}{lcc}
\hline $\begin{array}{l}\text { A gyors hatású } \\
\text { inzulin típusa }\end{array}$ & $\begin{array}{c}\text { Nem súlyos hypoglykaemia } \\
\text { (esemény/betegév) }\end{array}$ & $\begin{array}{c}\text { Súlyos hypoglykaemia } \\
\text { (esemény/betegév) }\end{array}$ \\
\hline Analóg & 1,88 & 0,06 \\
Humán & 1,74 & 0,21 \\
\hline
\end{tabular}


nem súlyos, 11 betegben pedig összesen 24 súlyos hypoglykaemiás eseményt. A nem súlyos és a súlyos hypoglykaemiás események incidenciasűrüségét a humán gyors hatású inzulint és a gyors hatású inzulinanalógot alkalmazók körében az 5. táblázat foglalja össze. A nem súlyos hypoglykaemiás események értékei csak kismértékben, a súlyos hypoglykaemiás események értékei viszont jelentősen különböztek egymástól - az előbbi esetben a humán, az utóbbiban az analóg gyors hatású inzulin javára. Az alcsoportok betegszámainak nagymértékű eltérése, valamint a súlyos hypoglykaemiás események összességében is kis száma miatt a csoportok statisztikai összehasonlításának nem volt értelme.

\section{Megbeszélés}

A jelen, beavatkozással nem járó vizsgálat („Solar”) célja az volt, hogy igazolja: a humáninzulin-kezelésről a glargin inzulin és gyors hatású inzulin kombinációjára való váltás jobb glykaemiás kontrollt biztosít, mint a megelőző humáninzulin-kezelés. A vizsgálat olyan betegek bevonásával készült, akiknek a bevonáskor 7,0\% vagy a feletti volt a $\mathrm{HbA}_{\mathrm{lc}}$-értékük, és a bevonást megelőző 12 hónapból legalább egy $\mathrm{HbA}_{\mathrm{lc}}$-mérési értékük rendelkezésre állt.

A bevonáskor a betegek átlagosan 58,3 évesek voltak, és átlagosan 10 éve diagnosztizálták náluk a 2-es típusú cukorbetegséget. A bevonáskor a betegek mintegy fele szenvedett már micro- és/vagy macrovascularis szövődményben.

A bevonást megelőző 12 hónapban a bázis- és a gyors hatású humán inzulin folyamatosan növelt adagja ellenére lényegében stagnált a betegek $\mathrm{HbA}_{\mathrm{lc}_{\mathrm{c}}}$-szintje. A bevonást követő 3 hónap glargin inzulinra alapozott bázisbolus inzulinkezelése mellett viszont - akár humán akár analóg gyors hatású inzulint kaptak - statisztikailag szignifikánsan és orvosilag is releváns mértékben csökkent körükben a $\mathrm{HbA}_{\mathrm{lc}}$, az éhomi vércukor és a postprandialis vércukor szintje. Bár a glargin inzulin mellett humán és analóg gyors hatású inzulint alkalmazó betegek számának jelentős eltérése miatt e két csoport statisztikai öszszehasonlítását nem végeztük el, annyi megállapítható volt, hogy a $\mathrm{HbA}_{\mathrm{lc}}$ és a postprandialis vércukor esetében az analóg, az éhomi vércukor esetében pedig a humán gyors hatású inzulint alkalmazó betegek körében volt nagyobb a csökkenés. A glykaemiás értékeken kívül a betegek testtömegindexe is szignifikáns mértékben, bár a rövid követési idő miatt csak kismértékben csökkent. A bevonáskor mért $\mathrm{HbA}_{1 \mathrm{c}}$-szint $(\leq 10 \%$ versus $>10 \%)$ és a BMI értéke $\left(\leq 30 \mathrm{~kg} / \mathrm{m}^{2}\right.$ versus $\left.>30 \mathrm{~kg} / \mathrm{m}^{2}\right)$ alapján képzett alcsoportokat vizsgálva kiderült, hogy a rosszabb vércukor-háztartású és a nagyobb súlyú betegek nagyobb kezdeti napi glargininzulin-dózist kaptak. A bázisinzulin aránya a bevonást megelőző 12 hónapban lényegében $40 \%$ körül stagnált, az arány a glargin inzulin és analóg gyors hatású inzulin kombinációjára váltást követően 45\%-ra emelkedett, ugyanakkor a glargin inzulin és humán gyors hatású inzulin kombinációjára váltás után 38\%-ra esett vissza. A terápia biztonságossága mellett szól, hogy a súlyos, tehát az elhárításához külső segítséget igénylő hypoglykaemiás esemény a betegek kevesebb, mint 1\%-át érintette. A hypoglykaemiás események incidenciasűrűségét összehasonlítva a nem súlyos eseményekben a humán, a súlyos eseményekben az analóg gyors hatású inzulin teljesített jobban.

A jelen obszervációs vizsgálat célja - hogy tudniillik a teljes humán bázis-bolus kezelésről a teljes analóg bázisbolus kezelésre való váltás vércukorháztartásra kifejtett hatását vizsgálja - a sajátos magyar finanszírozási rendszerre vezethető vissza, mely rendszer az analóg inzulinok magas arányú ártámogatása feltételeként elöírja bizonyos időtartamú humán bázis-bolus kezelés alkalmazását.

A eredmények értékelésének korlátját elsősorban a hatásossági elemzésből kimaradt betegek viszonylag nagy aránya, valamint a teljesen analóg és az analóg-humán inzulinkezelésben részesülők számának nagy különbsége és az ebből adódó elemzési korlátok jelentették.

A vizsgálat eredményei alapján megállapítható, hogy a glargin inzulinra alapozott bázis-bolus kezelés - akár analóg, akár humán inzulin a gyors hatású komponens már az első három hónapban a vércukorháztartás javulásához vezetett, összehasonlítva a váltást megelőző 12 hónapban tapasztalt, a folyamatosan emelt inzulindózisok ellenére észlelt stagnálással. Az elért kedvező eredmény interpretálása, elsősorban a nemzetközi tapasztalatokkal való összehasonlításban, nehéz feladat. A minimum 3 hónapig tartó humán bázis-bolus kezelés utáni analóg bázis-bolus kezelésre váltás az évek óta érvényes magyar finanszírozási rendszer következménye. Az így 'átváltott' betegek sajátos terápiás utat járnak be, a vércukorháztartásukban bekövetkezett változásokat azonban a nemzetközi gyakorlattal alig lehet érdemben összehasonlítani.

A humán inzulinon töltött időszak alatt regisztrált $\mathrm{HbA}_{\mathrm{lc}}$-értékek egyértelmúen felhívják a figyelmet a klinikai késlekedés problémájára [24]. Annak ellenére, hogy az alkalmazott inzulinok dózisának emelése nem javította a betegek anyagcserehelyzetét, a szakmai irányelvekben megfogalmazott terápia intenzifikálása jelentős késéssel történt meg [1]. Az inzulindózisnak a váltást követő emelése klinikailag is szignifikáns anyagcsere-javulást eredményezett. Érdemes kiemelni, hogy a klinikai szempontból komoly jelentőséggel bíró súlyos hypoglykaemiás események incidenciasűrüsége kisebb volt a teljes analóginzulin-kezelésben részesülők körében azokhoz képest, akik gyors hatásúként humán inzulint kaptak - ez a teljes analóginzulin-kezelés alkalmazásának biztonságosságát tükrözi. Ugyancsak az analóginzulin-kezelés gyakorlati elönyét mutatja az a tény, hogy a több, mint 1 százalékponttal javuló $\mathrm{HbA}_{\mathrm{lc}}$-értékek és az inzulindózisok emelése ellenére a betegek testsúlya nem nőtt a váltást követő időszakban. Bár gyakorlati tapasztalataink alapján elmondható, hogy a bázis-bolus inzulinarányok a humáninzulin-rendszerről az analóginzulin-rendszerre történő átállás során változnak, az ezzel kapcsolatos 
ajánlások elérhetősége nagyon korlátozott. Vizsgálatunk jellegéből adódóan ebből a szempontból gyakorlati ajánlást mi sem fogalmazhatunk meg, de a megfigyelés, hogy a bázisinzulin aránya a bolusinzulinhoz képest analóginzulin-kezelés mellett emelkedik, megerősíti az egyetlen elérhető gyakorlati útmutatóban megfogalmazott elveket [25].

Anyagi támogatás: A vizsgálat a Sanofi-Aventis Zrt. anyagi támogatásával zajlott. Dr. Nagy Erzsébet a SanofiAventis Zrt.-tól díjazásban részesült a jelen vizsgálat szakmai előkészítéséért, az abban vezető vizsgálóként való részvételéért és a kézirat elkészítéséért. Dr. Kovács Gábor a Sanofi-Aventis Zrt.-tôl díjazásban részesült a jelen vizsgálat szakmai előkészítéséért, a statisztikai kiértékelésben és a kézirat elkészítésében való közremúködéséért.

Szerzői munkamegosztás: N. E.: A hipotézisek kidolgozása. N. E., K. G.: A vizsgálat lefolytatása, statisztikai elemzések, a kézirat megszövegezése. A közlemény végleges változatát mindkét szerző elolvasta és jóváhagyta.

Érdekeltségek: A szerzőknek egyéb szempontból nincsenek érdekeltségeik.

\section{Köszönetnyilvánítás}

Köszönet illeti a vizsgálatban részt vevő valamennyi orvost a betegek toborzásáért és a vizsgálat lebonyolításáért.

\section{Irodalom}

[1] Diagnosis of diabetes mellitus, treatment and management of patients with diabetes. Guidelines of the Hungarian Diabetes Association, 2014. [A diabetes mellitus kórismézése, a cukorbetegek kezelése és gondozása a felnőttkorban. A Magyar Diabetes Társaság szakmai irányelve, 2014.] Diabetol Hung. 2014; 22(Suppl 1). [Hungarian]

[2] American Diabetes Association. Clinical Practice Recommendations. Diabetes Care 2013; 36(Suppl 1) 1-2.

[3] Home P, Chacra A, Chan J, et al. Considerations on blood glucose management in type 2 diabetes mellitus. Diabetes Metab Res Rev. 2002; 18: 273-285.

[4] Holman RR, Farmer AJ, Davies MJ, et al. Three-year efficacy of complex insulin regimens in type 2 diabetes. $\mathrm{N}$ Engl J Med. 2009; 361: 1736-1747.

[5] Bethel MA, Feinglos MN. Basal insulin therapy in type 2 diabetes. J Am Board Fam Pract. 2005; 18: 199-204.

[6] Jermendy G. Insulin treatment in type 1 and type 2 diabetes mellitus - advantages of long acting insulin analogues compared to NPH insulins. [Inzulinterápia l-es és 2 -es típusú diabetesben, a hosszú hatástartamú inzulinanalóg előnyei a hagyományos $\mathrm{NPH}$-inzulinnal szemben.] Available from: www.webdoki.hu [accessed: November 26, 2015]. [Hungarian]

[7] Hasslacher C, Lorenzo Bermejo J. Treatment with insulin analogs and prevalence of cardiovascular complications in patients with type 1 diabetes. Ther Adv Endocrinol Metab. 2017; 8: 149-157.

[8] Cammarota S, Falconio LM, Bruzzese D, et al. Lower rate of cardiovascular complications in patients on bolus insulin analogues: a retrospective population-based cohort study. PLoS ONE 2013; 8: e79762.
[9] Cammarota S, Bruzzese D, Catapano AL, et al. Lower incidence of macrovascular complications in patients on insulin glargine versus those on basal human insulins: A population-based cohort study in Italy. Nutr Metab Cardiovasc Dis. 2014; 24: 10-17.

[10] Gerő L. Insulin analogues in treatment of diabetes mellitus: advantages and disadvantages. [Inzulinanalógok a diabétesz kezelésében: előnyök és hátrányok.] Magy Orv. 2014; 22: 12-15. [Hungarian]

[11] Campbell RK, White JR, Levien T, et al. Insulin glargine. Clin Ther. 2001; 23: 1938-1957.

[12] Wang F, Carabino JM, Vergara CM. Insulin glargine: a systematic review of a long-acting insulin analogue. Clin Ther. 2003; 25: 1541-1577.

[13] Barnett AH. A review of basal insulins. Diabet Med. 2003; 20 : 873-885.

[14] Lantus cartridge - Summary of Product Characteristics (last revised: 14th July 2017).

[15] Dunn CJ, Plosker GL, Keating GM, et al. Insulin glargine: an updated review of its use in the management of diabetes mellitus. Drugs 2003; 63: 1743-1778.

[16] Porcellati F, Lucidi P, Cioli P, et al. Pharmacokinetics and pharmacodynamics of insulin glargine given in the evening as compared with in the morning in type 2 diabetes. Diabetes Care 2015; 38: 503-512.

[17] Ratner RE, Hirsch IB, Neifing JL, et al. Less hypoglycemia with insulin glargine in intensive insulin therapy for type 1 diabetes. U.S. Study Group of Insulin Glargine in Type 1 Diabetes. Diabetes Care 2000; 23: 639-643.

[18] Rosenstock J, Schwartz SL, Clark CM Jr., et al. Basal insulin therapy in type 2 diabetes: 28 -week comparison of insulin glargine (HOE 901) and NPH insulin. Diabetes Care 2001; 24: 631-636.

[19] Pieber TR, Eugene-Jolchine I, Derobert E. Efficacy and safety of HOE 901 versus NPH insulin in patients with type 1 diabetes. The European Study Group of HOE 901 in Type 1 Diabetes. Diabetes Care 2000; 23: 157-162.

[20] Mullins P, Sharplin P, Yki-Jarvinen H, et al. Negative binomial meta-regression analysis of combined glycosylated hemoglobin and hypoglycemia outcomes across eleven Phase III and IV studies of insulin glargine compared with neutral protamine Hagedorn insulin in type 1 and type 2 diabetes mellitus. Clin Ther. 2007; 29: 1607-1619.

[21] Davies M, Storms F, Shutler S, et al. Improvement of glycemic control in subjects with poorly controlled type 2 diabetes: comparison of two treatment algorithms using insulin glargine. Diabetes Care 2005; 28: 1282-1288.

[22] Abrahamian H, Ludvik B, Schernthaner G, et al. Improvement of glucose tolerance in type 2 diabetic patients: traditional vs. modern insulin regimens (results from the Austrian Biaspart Study). Horm Metab Res. 2005; 37: 684-689.

[23] Hidvégi T, Kovács G. The effect of patient education on glycemic status and self-monitoring activity in type 2 diabetic patients recently switched to basal insulin analogue treatment. [Bázisinzulinanalóg-kezelés elkezdésével együtt végzett csoportos betegedukáció hatásának vizsgálata a glykaemiás értékekre és az önellenőrzési aktivitásra.] Orv Hetil. 2014; 155: 1713-1721. [Hungarian]

[24] Khunti K, Wolden ML., Thorsted BL, et al. Clinical inertia in people with type 2 diabetes: A retrospective cohort study of more than 80,000 people. Diabetes Care 2013; 36: 3411-3417.

[25] Deák L. Reflections of a clinician on the switch from human to analogue insulin treatment. [A klinikus gondolatai a humánanalóg inzulinkezelés váltása kapcsán.] Orv Hetil. 2012; 153: 1589-1593. [Hungarian]

(Nagy Erzsébet dr., Budapest, Örs vezér tere 23., 1148 e-mail: nagyzsoka1026@gmail.com) 